\title{
Simpson-Golabi-Behmel Syndrome
}

National Cancer Institute

\section{Source}

National Cancer Institute. Simpson-Golabi-Behmel Syndrome. NCI Thesaurus. Code C131002.

An X-linked recessive syndrome caused by mutation(s) in the GPC3, OFD1, or rarely the GPC4 gene, encoding glypican 3, oral-facial-digital syndrome 1 protein, and glypican 4, respectively. The condition is characterized by macrosomia, coarse facies,

cryptorchidism, cong enital heart, kidney, liver, spleen, and musculoskeletal abnormalities. 